\title{
Economic Integration Effects on Trade Margins : Sectoral Evidence from Latin America
}

\author{
Laura Márquez-Ramos \\ Universitat Jaume I, Castellón de la Plana, Spain \\ Luis Marcelo Florensa \\ Instituto de Economía y Finanzas- Universidad Nacional de Córdoba, Córdoba, Argentina \\ María Luisa Recalde \\ Instituto de Economía y Finanzas- Universidad Nacional de Córdoba, Córdoba, Argentina
}

\begin{abstract}
The present paper aims to determine the effects of different levels of economic integration on the intensive and the extensive margins of trade. Specifically, the analysis focuses on the case of Latin America. It is of great importance for development policies in the region since the extensive margin can be defined as those exports that provide new market entrants, while the intensive margin is due to continued growth in sales of old exporters to the same destinations. Therefore, obtained results have important policy implications related to diversification strategies. The long-term period considered will allow us to determine whether different effects on trade margins might arise in the following two sub-periods: 1962 1989 and from 1990 onwards, i.e. before and after the spread of regional integration agreements and the deepening of the liberalization process
\end{abstract}

\footnotetext{
* Corresponding Author: Laura Márquez-Ramos; Department of Economics and Institute of International Economics, Universitat Jaume I, Campus del Riu Sec, 12071 Castellón de la Plana, Spain; Tel: +34 964387166. Fax: +34 964728591. E-mail: 1marquez@eco.uji.es.

Co-Author: Luis Marcelo Florensa; Instituto de Economía y Finanzas, Universidad Nacional de Córdoba, Av. Valparaíso s/n, Ciudad Universitaria, X5000HRV Córdoba, Argentina; Tel: +54 3514437300, E-mail: florensa@eco.unc. edu.ar.

María Luisa Recalde; Instituto de Economía y Finanzas- Universidad Nacional de Córdoba, Av. Valparaíso s/n, Ciudad Universitaria, X5000HRV Córdoba, Argentina; Tel: +54 3514437300, E-mail: 1recalde@eco.unc. edu.ar.
} 
in the region. Finally, we focus on those specific sectors in which Latin American countries present a higher relative participation of trade. The obtained results show that the effect of economic integration is both time and period sensitive. The main positive effects are found to be reflected in the intensive margin for all different types of agreements. Moreover, we find that deeper economic integration agreements have the greatest effect on trade margins.

\section{JEL Classifications: F14, F15}

Keywords: Economic Integration, Extensive Margin, Intensive Margin, Latin America, Panel Data

\section{Introduction}

Increasing knowledge of the consequences that the dynamics of shallow versus deep ${ }^{1}$ economic integration has in Latin America, in terms of trade margins and in different sectors, is highly desirable. It seems that a new stage of regional integration is starting in the region (Peña 2011). In this sense, it is important to note that there has been a considerable growth in the number of Economic Integration Agreements (EIAs) since the 1990s, and that, over the last two decades of this new wave of regionalism, not only the number of EIAs has increased significantly, but also the increased complexity of the regionalization process. For example, there has been an increase of North-South agreements, as well as the creation and the enhancement of deeper economic integration agreements.

This paper seeks to determine the effects of different levels of Latin American EIAs

Acknowledgements: The authors thank Maria Victoria Barone for her active and valuable research assistance. We also thank German Gonzalez and Pedro Degiovanni for their participation in database processing, and very gratefully acknowledge the support and collaboration of SECYT, Universidad Nacional de Córdoba, Universitat Jaume I and Generalitat Valenciana (SECYT 05/E349; P1•1B2013-06; PROMETEOII/2014/053). We would also like to thank Jesica De Angelis, Juan Carlos Hallak and Jordi Paniagua, an anonymous referee, the editor and the participants in the ETSG held in Birmingham in September 2013, the Annual Meeting of the Asociación Argentina de Economía Política held in Rosario in November 2013, and in the X Conference on Economics Integration (INTECO) held in Castellón de la Plana in November 2013, for their very helpful comments and suggestions.

In this paper we take into account two integration levels: shallow EIAs (Non-Preferential Trade Agreements) and Preferential Trade Agreements and deep EIAs (Free Trade Agreements and Customs Unions). 
on the intensive and the extensive margins of trade. This issue is very important and in line with the latest trade literature. In addition, as we are aware that the effect of trade liberalisation on trade margins in developing countries might be period sensitive, we distinguish two different periods.

According to Grugel (2004), new regionalism provides a framework for the ordering and regulation of the South; however, there have been important differences between the models of new regionalism followed by the Latin American developed partners. Specifically, although both the European Union (EU) and the United States aim to push economic liberalisation in the Southern Cone, Europe is more explicitly concerned with politics and institution-building than the US market-led pattern of new regionalism and endorses a North-South model of global cooperation in which the North assumes some responsibilities for the development of the South (Grugel 2004). Nonetheless, it is important to point out that Pomfret (2007) concludes that the long-term dynamics of EIAs lead to ineffectiveness in the majority of cases, and points out that the increased complexity of regional arrangements open up opportunities for managed trade that can benefit insiders and become a stumbling block to progress at a global level (p. 940). Previous research (Florensa et al. 2013 and 2014) analyses the consequences of Latin American economic integration on trade margins over the periods of 1962 2005 and 1962 2009, respectively. The results show that the signed integration agreements in the region have positively affected the intensive and extensive margins of trade and that the deepest integration agreements have a bigger impact on trade margins than shallower ones. However, when the effect of economic integration is analysed for different sectors (primary goods and agricultural manufactures, industrial manufactures and mineral fuels, lubricants and related materials), the deepest integration agreements do not seem to have fostered exports of new industrial products (the extensive margin does not increase) although both deeper and shallower agreements seem to have maintained and enhanced the trade relations of primary goods and agricultural manufactures (the intensive margin increases) over time.

The present paper goes further than the existing literature by analysing the effect of EIAs on trade margins in two different periods, and by using a more disaggregated trade classification. In particular, we consider the two above mentioned forms of integration, known as the old and new regionalisms (Baier et al. 2006) by focusing on two subperiods: 1962 1989 and 1990 2009. We then focus on those specific sectors in which Latin American countries present a higher relative participation.

Our results point to the idea that the extensive and intensive margins of trade have 
increased with the spread of new generation agreements in those sectors in which the considered developing nations export to a greater extent. These results have important policy implications as an increase in the extensive margin can be understood as a diversification of the export matrix and hence the structure of domestic production, while an increase in intensive margin can result in the concentration of the export matrix. Obtaining a higher positive effect of deeper agreements on the extensive margin of different sectors would be in line with development and industrialisation objectives in the region.

This paper is divided into seven parts: after the introduction in Section I, Section II presents a brief description of the Latin American integration process. Section III justifies the measurement of trade margins as defined by Hummels and Klenow (2005) in our framework ${ }^{2}$; i.e., a gravity equation that allows the analysis of the effect of shallow and deep EIAs on trade margins over different time periods while dealing with the endogeneity of EIAs. Section IV describes the methodology; Section V describes data, sources, and variables and includes a descriptive analysis. Section VI shows the main results that aim to answer whether the effect of economic integration on trade margins is period-sensitive. It also includes the analysis for specific sectors. The final section concludes.

\section{The Economic Integration Process in Latin America}

The group of 11 Latin American countries under analysis signed a significant number of EIAs over the period 1962 2009. ${ }^{3}$ First, the 1960 Montevideo Treaty created the Latin American Free Trade Association (LAFTA), signed initially by Argentina, Brazil, Chile, Mexico, Paraguay, Peru, and Uruguay. As of 1970, LAFTA has expanded to include four more countries: Bolivia, Colombia, Ecuador, and Venezuela. The signatories hoped to create a common market in Latin America and offered tariff rebates among member nations. LAFTA came into effect in January of 1962 and was superseded in 1980 by the Latin American Integration Association (LAIA). Cuba was the last country to accede,

\footnotetext{
${ }^{2}$ We are grateful to an anonymous referee for this suggestion.

${ }^{3}$ Tables A.1, A.2, and A.3 in Florensa et al. (2014) summarize this information.
} 
becoming a full member of LAIA in 1999. LAIA is today the largest Latin American integration group and includes all 11 exporting countries of the analyzed sample of countries.

The Andean Pact came into existence with the signing of the Cartagena Agreement in 1969 by Bolivia, Chile, Colombia, Ecuador, and Peru. In 1973, the mentioned pact gained its sixth member, Venezuela. In 1976, however, its membership was again reduced to five when Chile withdrew. Venezuela announced its withdrawal in 2006, reducing the Andean Community to four member states. The Andean Community (or CAN, called the Andean Pact until 1996) is today a Customs Union (CU).

The Mercosur was created in 1991 by the Asuncion Treaty and was signed initially by Argentina, Brazil, Paraguay, and Uruguay. It became a Customs Union in 1995 but, in practice, it is still an imperfect CU (Phillips 2003). Bolivia and Chile have been associate members since 1996, Peru since 2003, and Colombia, Ecuador, and Venezuela since 2004. Paraguay was suspended in $2012 .{ }^{4}$ Venezuela has recently been incorporated into Mercosur; and Bolivia is in accession process.

Following the new cooperation agreement with Mercosur, the Andean Community gained four new associate members: Argentina, Brazil, Paraguay, and Uruguay. These four Mercosur members were granted associate membership in 2005. Countries in other regions have also signed agreements with LAIA members. For example, over the time period considered, the European Economic Area (EEA) ${ }^{5}$ has signed an integration agreement with Chile and Mexico, the Caribbean Community and Common Market (CARICOM) with Colombia and Venezuela, and Canada, Mexico, and the United States with the North America Free Trade Agreement (NAFTA). Finally, Chile signed the Trans-Pacific Strategic Economic Partnership with Brunei, New Zealand and Singapore in 2007.

Chile has signed the largest number of bilateral agreements in the region: with Bolivia, Canada, China, Colombia, Costa Rica, El Salvador, Honduras, India, Japan, Mexico, Korea, Panama, Peru, Venezuela, and the United States. In fact, Chile has undergone the farthest-reaching liberalisation process in the Latin American region over the period 1994 2008 and, together with Mexico, seems to have liberalised relatively

\footnotetext{
${ }^{4}$ Paraguay rejoined Mercosur in 2013.

5 The European Free Trade Association (EFTA) is a trade bloc created in 1960 by Austria, Denmark, the United Kingdom, Norway, Portugal, Sweden, and Switzerland. Finland became a member in 1961, Iceland in 1970, and Liechtenstein in 1991. Following the abandonment of EFTA and the entry into the European Community of the United Kingdom and Denmark in 1973, Portugal in 1986, and Austria, Sweden, and Finland in 1995, the importance of EFTA diminished. Today, this block consists of Switzerland, Iceland, Liechtenstein, and Norway, and they have a free trade area with the EU (European Economic Area, or EEA for its acronym in English).
} 
more within other integration agreements, such as the NAFTA and the EU, than within LAIA (Florensa et al. 2011; Florensa et al. 2015b). Mexico is also worth highlighting for having signed a number of important bilateral agreements. It signed EIAs with Bolivia, Chile, Colombia, Costa Rica, Israel, Japan, and Nicaragua. Other bilateral agreements are Guatemala-Venezuela and Peru-United States.

An important number of developed countries have signed non-reciprocal agreements with developing countries; for example, Japan and Norway in 1971, New Zealand in 1972, Australia and Canada in 1974, Russia in 1994, and Turkey in 2002. They all signed the Generalized System of Preferences with all LAIA countries. ${ }^{6}$

\section{Measuring Trade Margins}

Since the 1950's (Viner 1950), many authors have contributed to the debate of the effects of EIAs on trade gains among member countries. Since the early 1990's, there has been a considerable increase in the number of studies based on gravity models, among which are Eichengreen and Frankel (1995), Frankel et al. (1996 and 1998), Soloaga and Winters (2001), Magee (2008). Most of these works imply that all products are traded with all destinations; however, empirical evidence indicates that only a few firms export and these exporters sell to a limited number of countries. This situation has led to the development of new theories concerning international trade based on the heterogeneity of firms (only the most productive export) and the existence of fixed exporting costs (Melitz 2003). It is worth analyzing whether an increase in a country's exports is due to maintaining and enhancing trade relations over time (Intensive Margin or IM) or to the appearance of new products and markets (Extensive Margin or EM).

In relation to the studies that provide background to this work, it is worth mentioning Hummels and Klenow (2005) and Baier et al. (2011 and 2014). For the effect of specific EIAs, Hillberry and McDaniel (2003) focus on the NAFTA, and Bensassi et al. (2012) focus on the effects of the Barcelona Process on North African countries. Kehoe and Ruhl (2013) focus on the importance of the EM on the growth in trade not only among

\footnotetext{
${ }^{6}$ To sum up, there has been a gradual disappearance of new agreements under the Generalized System of Preferences, with concessions granted by developed to developing countries. Additionally, there is a proliferation of bilateral agreements between countries in the region and between countries and trading blocs that already existed (Florensa et al. 2014).
} 
NAFTA members, but also between the US and third trading partners. These authors find that the EM is more important over longer time frames and show that the EM is a significant contributor to trade growth during trade liberalisation or periods of structural change although it is not highly important for country pairs with a stable policy.

Hummels and Klenow (2005) found that the extensive margin accounts for $60 \%$ of export growth in major economies. From a different perspective, Hillberry and McDaniel (2003) apply a decomposition of growth in trade which provides evidence about whether the United States has traded more of the same products with partners in NAFTA since 1993, or whether they have traded new products. Their results show that both margins coexist after the creation of NAFTA. Bensassi et al. (2012) follow the decomposition of trade proposed by Hillberry and Hummels (2008) and they show that North African countries enjoyed significant positive returns from the Barcelona Process through increased exports of manufactured products to the European Union (EU). Abraham et al. (2011) use two alternative measures of each of the margins: the average value of exports per product and the count measure of newly established trade flows between countries, as well as the Hummels and Klenow (2005) decomposition. These authors find that, by using the Hummels and Klenow decomposition, their results at macro-level are similar to those obtained previously at firm-level. This methodology has also been followed by Baier et al. (2011 and 2014), Soete and Van Hove (2013), and Florensa et al. (2013, 2014 and 2015a). Following these authors, we analyze the effects of different economic integration agreements on the intensive and extensive margins by computing the Hummels and Klenow (2005) indices.

\section{Methodology}

By using a panel of bilateral trade flows of goods for a large number of countries and for the period 1962 2009, we will distinguish the effects of different levels of integration in the signed arrangements. The length of this period will allow us not only to study the short and long-term effects, but also to divide it into two different sub-periods, i.e., before and after the spread of Latin American EIAs in the 90s.

With respect to estimating the effects of EIAs, if this variable is correlated with the error term in gravity equations, it is econometrically endogenous and ordinary least 
squares can lead to biased and inconsistent coefficient estimates. ${ }^{7}$ In order to eliminate endogeneity bias from the variable EIA, Baier and Bergstrand (2007) and Baier et al. (2011) propose the use of panel techniques and estimation by Fixed Effects (FE) of the following Equation (1):

$$
\ln X_{i j t}=\beta_{0}+\beta_{1} E I A_{i j t}+\eta_{i j}+\delta_{i t}+\psi_{j t}+\varepsilon_{i j t}
$$

where $\eta_{i j}$ is a country-pair fixed effect to capture all time-invariant bilateral factors influencing nominal trade flows; $\delta_{i t}$ and $\psi_{j t}$ are exporter-time and importer-time fixed effects, respectively, to capture time-varying exporter and importer GDP, as well as all other time-varying country-specific effects that are unobservable in $i$ and $j$ and influence trade, including the exporter's and importer's multilateral price resistance terms.

In order to address the issue of the timing effects of EIAs, we use an additional equation:

$$
\ln X_{i j t}=\alpha_{0}+\alpha_{1} E I A_{i j t}+\alpha_{2} E I A_{i j t-5}+\alpha_{3} E I A_{i j t-10}+\eta_{i j}+\delta_{i t}+\psi_{j t}+\varepsilon_{i j t}
$$

Equation (2) generalizes Equation (1) by including five and ten - year lags of the EIA variable to distinguish current and lagged effects $\left(E I A_{i j t-5}\right.$ and $E I A_{i j t-10}$, respectively). In the empirical analysis, we estimate Equation (1) and (2), whereby $X_{i j t}$ might denote the value of exports of goods from country $i$ to $j$ in the year $t$ (TRADE), the EM, or the IM. ${ }^{8}$

As pointed above, following Baier et al. (2011 and 2014), Soete and Van Hove (2013), and Florensa et al. (2013 and 2014), we employ the methodology developed in Hummels and Klenow (2005) to obtain the EM and the IM. ${ }^{9}$ This methodology can be used in a panel that permits the use of the indicators employed in the construction of $E M_{i j t}$ and $I M_{i j t}$ so that they may vary over time. Furthermore, the log of the value of trade flows

\footnotetext{
${ }^{7}$ For a complete explanation of this issue, see Baier and Bergstrand (2007) and Baier et al. (2011).

${ }^{8}$ We also estimate a third Equation based on the Fifth-Differences (FD) as follows (Baier et al. 2014): $\Delta_{5} \ln X_{i j t}=\gamma_{0}+\gamma_{1}\left(\Delta_{5} E I A_{i j t}\right)+\gamma_{2}\left(\Delta_{5} E I A_{i j,(t-5)-(t-10)}\right)+\delta_{i t}+\psi_{j t}+\eta_{i j}+\Delta_{5} \varepsilon_{i j t}$

These results have not been included in the paper to save space, but they are available upon request. We rely on fixed effects regressions as they might soften the dramatic variations that might exist in a given period.

Also note that we are controlling for all types of integration in the regressions and then, for example, in Equation (1) we estimate: $\ln X_{i j t}=\beta_{0}+\beta_{1} N R P T A_{i j t}+\beta_{2} P T A_{i j t}+\beta_{3} F T A_{i j t}+\beta_{4} C U_{i j t}+\eta_{i j}+\delta_{i t}+\psi_{j t}+\varepsilon_{i j t}$

Here, the four types of EIAs denote Non-reciprocal or one-way Preferential Trade Agreements (NRPTA), two-way Preferential Trade Agreements (PTA), Free Trade Agreements (FTA), and Customs Unions (CU), respectively.

${ }^{9}$ This methodology used bilateral trade flows at a high level of disaggregation of products seeking to explain the growth in exports by major exporting quantities of a particular good (IM) or a wider range of goods (EM). Note that using minimum thresholds by category (instead of zero) to classify a product as active might not be a better strategy in our context. As when Kehoe and Ruhl (2013) use a fixed cut-off to determine a good's trade status, they are not able to capture the changing composition of trade.
} 
from $i$ to $j$ in the year $t$ can be decomposed linearly into logs of the extensive margin, the intensive margin and the value of $j$ 's imports from the world $\left(\ln X_{j t}\right)$. This term, as we use estimations with fixed effects, is included in the fixed time-importer effects $\psi_{j t}$.

\section{Empirical Analysis}

\section{A. Data}

In order to perform the empirical analysis, two main sources of data have been used: bilateral trade flows and a polychotomous variable representing the level of economic integration the agreement entails. ${ }^{10}$ For the construction of the database, yearly bilateral trade flows for the period 1962 2009 were taken into account. Trade data for the period 1962 2000 were obtained from the National Bureau of Economic Research (NBER)United Nations trade data set, ${ }^{11}$ and documented in Feenstra et al. (2005), whereas WITS (COMTRADE) was used for the period 2001 2009. In both cases, the data are classified according to 4-digit Standard Industrial Trade Classification (SITC), Revision 2. The exporting countries are the 11 members of LAIA (Argentina, Bolivia, Brazil, Chile, Colombia, Ecuador, Mexico, Peru, Paraguay, Venezuela, and Uruguay) ${ }^{12}$ while the importers are the 161 destination countries as shown in Table A in the Appendix. In addition, we had to build a database with the same characteristics (period and classification of goods), considering the world as an exporter and the 161 destination countries as importers in order to calculate the margins of trade.

The variable indicating the level of integration between country pairs takes the form of a polychotomous index built by Baier et al. (2011). ${ }^{13}$ The Baier et al. (2011) polychotomous indexes for the period 1962 2005 were checked by the documents available in this database and also by the EIA set out in the website of the World Trade Organization (WTO). We have completed the polychotomous index from 2006 to 2009

\footnotetext{
${ }^{10}$ Polychotomous variables are categorical variables that can be classified into many categories.

${ }^{11}$ Available at http://cid.econ.ucdavis.edu/data/undata/undata.html.

${ }^{12}$ Cuba has been a member since 1999, but it is not considered in the empirical analysis because trade data is available only for some years of the period.

${ }^{13}$ Available at www.nd.edu/ jbergstr/.
} 
for our sample of countries. Specifically, the index is defined as follows: (0) when there is no EIA, (1) when an agreement is asymmetrical or one-way Non-reciprocal Preferential Trade Agreement (NRPTA), (2) when an agreement corresponds to twoway Preferential Trade Agreements (PTA), (3) when it defines Free Trade Agreements (FTA), and (4) when an agreement refers to Customs Unions (CU).

Initially, the analysis is performed for all goods pooled together over the period 1962 2009, and for the two sub-periods considered. Afterwards, we run regressions for different sets of products. In particular, we focus on the ten sectors where LAIA countries have the greatest relative participation of world exports.

With respect to the sectors taken into account, we selected a group of 8 divisions out of all the divisions included in the SICT, and an additional category that includes the combination of divisions 61 and 85. Our selection has taken into account the following criteria: (i) the share over the total value of exports, (ii) the relative participation over the total number of observations, and (iii) the inclusion of those divisions that represent the two main export sectors in LAIA where the first is the primary goods and agricultural manufactures and the second is the industrial manufactures. The selected sectors represent an average of $33 \%$ of LAIA exports and $28.3 \%$ of observations over the period 1962 2009. We subsequently focus on the most traded goods, opposite to Kehoe and Ruhl (2013) who focus on the least traded goods.

The first and second columns in Table B in the Appendix shows the selected sectors. The third column shows the number of observations. The fourth column shows the participation of each sector in the total number of observations, while the last column lists the participation of each sector in the value of total exports. Sectors are ordered from higher to lower importance according to the indicator in the last column.

\section{B. Descriptive analysis}

Firstly, we study the evolution of the participation in exports of the analysed sectors by different levels of EIAs. This supposes an interesting test to clarify the differential impact by period that we might expect arising at different levels of economic integration. ${ }^{14}$

Overall, there is a growing export share of the LAIA countries with countries they

\footnotetext{
${ }^{14}$ These figures are available upon request.
} 
hold some type of trade agreement. In the case of NRPTAs (EIA=1), it can be seen that for most of the sectors, there was a significant increase in the share of exports up to the early 90s; thereafter, the trend is reversed with the spread of the deepest trade agreements (FTAs and CUs). In the case of PTAs $(\mathrm{EIA}=2)$, there is a decrease in the share of exports of all sectors, which is maintained throughout the period, except for cereals. This increase in the share of cereals probably occurs because some destination countries with $\mathrm{EIA}=0$ become countries with $\mathrm{EIA}=2$.

With respect to the FTAs $(\mathrm{EIA}=3)$, there has been a marked increase in the share of exports of cereals, vegetables and fruit, and non-ferrous metals as from the signature of this kind of agreement. Concerning the rest of the items in the analysis, an increase is observed up to the end of the 90 s when stabilization takes place or there is a slight share decrease.

Three different performance types can be seen in relation to CUs (EIA=4). The textile, road vehicles, ${ }^{15}$ and leather sectors show a decreasing share up to the start of the present century when the trend is reversed. Cereals and industrial machinery exhibit a diminishing share over the period while the share is almost constant for the remaining sectors.

Secondly, it is worth introducing figures of the time evolution of the EM and the IM for all the goods pooled together. Figures A and B in the Appendix show the evolution of the EM and the IM, respectively, in four representative countries in the region i.e., Argentina, Brazil, Chile, and Mexico. We can observe the highest values for the IM at the beginning of the second time period taken into account, and that the IM has decreased importantly after the Latin American economic crises at the beginning of the present century. Otherwise, the EM seems to have increased considerably during the second wave of regionalism, being quite stable during the years of crisis, but increasing sharply as from 2001 onwards.

\footnotetext{
${ }^{15}$ Concerning the Mercosur automotive policy, it is important to note that there is a particular agreement that also affects the sector of road vehicles.
} 


\section{Main Results}

\section{A. All goods}

Tables 1 and 2 show the main results of our regressions. Each table reports the results for three alternative LHS variables: bilateral trade (trade), Extensive Margin (EM), and Intensive Margin (IM). Additionally, we have vertically ordered the list of existing EIAs from shallower to deeper economic integration.

Tables 1 and 2 show the results obtained when Equation (1), i.e., without lags for the variables of interest, and Equation (2), which includes lagged values of EIA dummies, are estimated, respectively. Table 1 shows that the estimated coefficients for the IM of NRPTA and PTA are negative and significant when the full period is taken into account. Negative and significant coefficients for shallower trade agreements are also obtained by Baier et al. (2011) and Florensa et al. (2013 and 2014); however, this result might be partially explained by a differential trend in the IM in different sub-periods. Whereas in the first period the IM is negative for NRPTAs and PTAs, it is positive and significant in the case of the IM for PTA in the second period. The coefficient for EM of PTA over the first period is positive and significant although it is negative over the second; the overall effect on the EM is positive and statistically significant. For the deepest EIAs (FTA and $\mathrm{CU})$, trade, EM, and IM coefficients are positive in Equation (1) when the entire period is taken into account although the coefficient of FTA is not significant on the intensive margin. Additionally, the effect on IM is larger than on EM in the case of CU.

When we focus on the second sub-period that covers the increase of deeper EIAs and other integration agreements in which developed countries are involved, positive and significant coefficients of FTAs and CUs are obtained for trade and the IM in the current period. Based on the characteristics of the EIAs, previous research found that the deepest integration agreements have a greater effect on trade margins than shallower ones (Baier et al. 2011 and 2014, Florensa et al. 2013 and 2014). Nonetheless, when different time periods and exports of all goods are pooled together to analyze the effect of different EIAs on the EM and the IM, it seems that the deepest integration agreements in Latin America have fostered exports of new products although the PTAs signed over the period 1962 1989 (LAIA and the agreements under the Generalized System of Preferences) have increased the extensive margin to a higher extent.

Columns 1-3 in Table 2 show a positive and significant coefficient for the 5-year lag 
of FTAs on the intensive margin, for the CU on both the EM and the IM, and for the 5-year lag of the variable CU on the intensive margin. Moreover, the CU has the greatest positive effect on both margins of trade, but it is in the intensive margin of trade where the positive and significant effect of economic integration seems to persist after 5 years.

In particular, the sum of the estimated coefficients for the CU and L5.CU variables is 0.741 when the dependent variable is the logarithm of the intensive margin. If a Latin American country engages in a customs union, the intensive margin of its exports increases by $110 \%\left(\left[e^{0.741}-1\right] * 100\right)$, and most of the observed effects is achieved after five years.

When different sub-periods are considered, the 10-year lag of PTAs, FTAs, and CUs, and the 5-year lag of FTAs and CUs have a positive and significant effect on the intensive margin in the second sub-period. These results indicate not only that it is worth taking long-term effects into account when analyzing the effect of regional integration in Latin American countries, but also that the agreements signed in the second subperiod have a more persistent effect on trade margins and, specifically, on the IM. In sum, during the second sub-period, both deeper and shallower agreements seem to have maintained and enhanced trade relations over time, and this positive effect occurs also in the long term. We also show that the most recent Latin American trade integration has contributed to increasing the concentration of the export matrix. Finally, the obtained results show that the effect of economic integration is sensitive to the period of time taken into account. ${ }^{16}$

\footnotetext{
${ }^{16}$ The results obtained in Equation (3) are in line with those obtained with Equation (1) and (2). As Equation (1) and (2) seem to be capturing both the short and the long-term effects in a more accurate way than Equation (3) for different sub-periods, these are our preferred equations.
} 
Table 1. Main results for all goods

for Equation (1)

\begin{tabular}{|c|c|c|c|c|c|c|c|c|c|}
\hline & \multicolumn{3}{|c|}{ 1962 2009 } & \multicolumn{3}{|c|}{$1962 \sim 1989$} & \multicolumn{3}{|c|}{ 1989 2009 } \\
\hline & TRADE(1) & $\mathrm{EM}(2)$ & $\operatorname{IM}(3)$ & TRADE (4) & EM (5) & $\operatorname{IM}(6)$ & TRADE (7) & EM (8) & IM (9) \\
\hline \multirow{2}{*}{ NRPTA } & $-0.288 * * *$ & -0.027 & $-0.263 * * *$ & -0.457 & 0.007 & -0.465 & -0.068 & -0.059 & -0.011 \\
\hline & -2.906 & -0.325 & -2.781 & -1.321 & 0.025 & -1.442 & -0.66 & -0.64 & -0.10 \\
\hline \multirow{2}{*}{ PTA } & -0.007 & $0.123^{* *}$ & $-0.130^{*}$ & 0.166 & $0.611^{* * *}$ & $-0.445^{* * *}$ & $0.191^{*}$ & $-0.148^{*}$ & $0.340 * * *$ \\
\hline & -0.088 & 2.014 & -1.832 & 1.247 & 5.627 & -3.595 & 1.93 & -1.68 & 3.37 \\
\hline \multirow{2}{*}{$F T A$} & $0.313^{* * *}$ & $0.185^{* *}$ & 0.129 & . & . & . & $0.386 * * *$ & 0.002 & $0.384 * * *$ \\
\hline & 3.521 & 2.527 & 1.519 & . & . & . & 3.97 & 0.02 & 3.90 \\
\hline \multirow{2}{*}{$C U$} & $0.914 * * *$ & $0.250 * * *$ & $0.663 * * *$ & . & . & . & $0.778 * * *$ & -0.058 & $0.836^{* * *}$ \\
\hline & 7.828 & 2.608 & 5.972 & . & . & . & 5.77 & -0.48 & 6.12 \\
\hline $\begin{array}{l}\text { Number of } \\
\text { observations }\end{array}$ & 45,303 & 45,304 & 45,303 & 22,784 & 22,784 & 22,784 & 27,071 & 27,072 & 27,071 \\
\hline $\mathrm{R}^{2}$ & 0.69 & 0.49 & 0.47 & 0.62 & 0.39 & 0.39 & 0.43 & 0.52 & 0.53 \\
\hline
\end{tabular}

(Notes) (i) $* * *$ denote statistically significant at $1 \%$,

$* *$ denote statistically significant at $5 \%$,

* denote statistically significant at $10 \%$.

(ii) T-statistics are provided below every coefficient. 


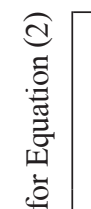

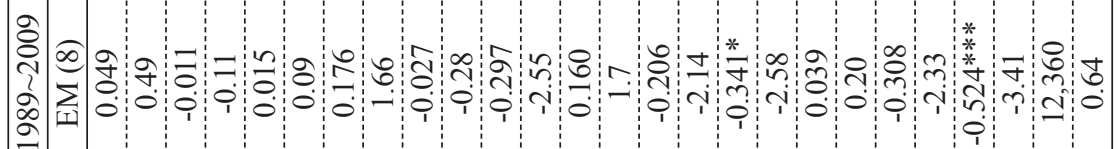

$\widehat{E}$

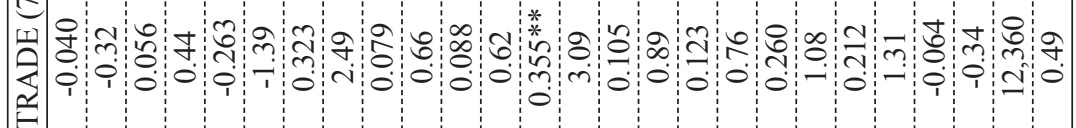

ق

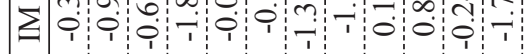

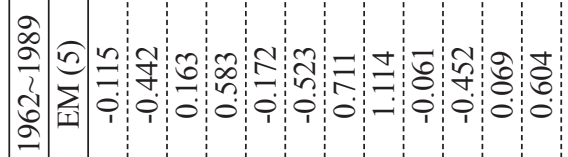

$\infty$

0

Ð

牙当

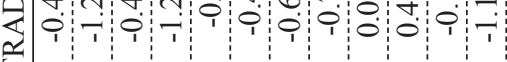



o 0

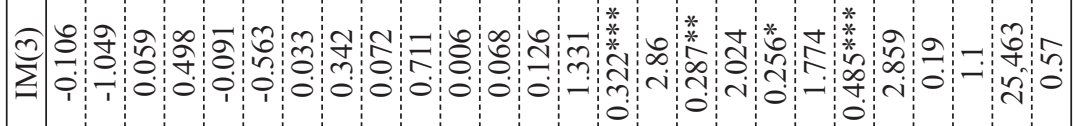

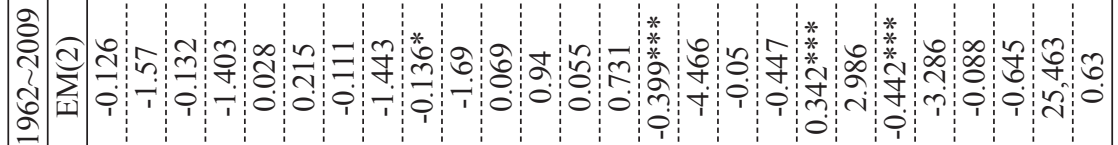

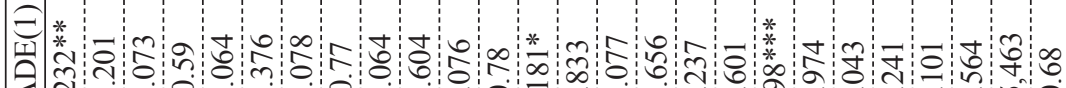

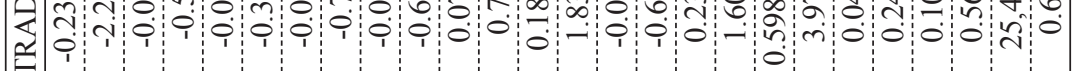

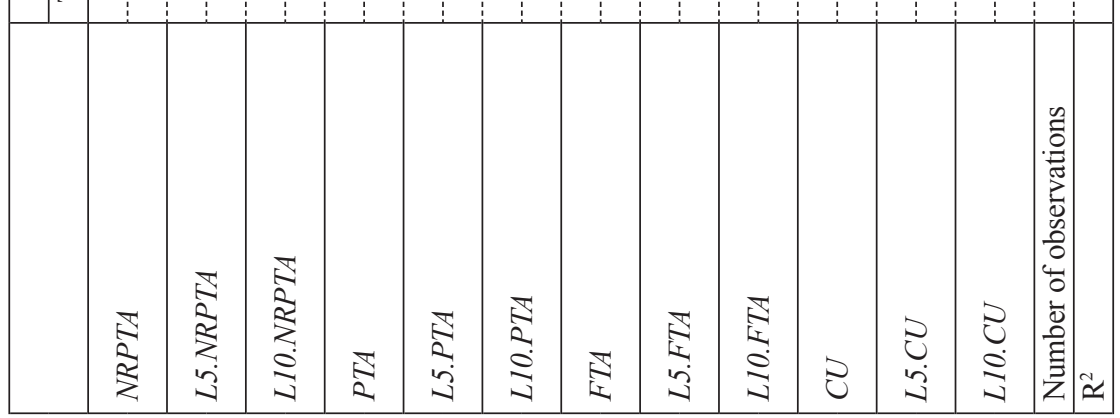




\section{B. By sector ${ }^{17}$}

Tables 3 6 show separately the effects of different levels of EIAs: Table 3 for NRPTAs, Table 4 for PTAs, Table 5 for FTAs, and Table 6 for CUs. These tables take into account the exports of all sectors pooled together as well as the specific sectors defined in Section $\mathrm{V}$ as shown in Table B. In addition, regressions of the entire period of 1962 2009, and the sub-period of 1989 2009 are shown separately. These tables show the convenience of distinguishing among different divisions: in the previous sub-section, when all goods were pooled together, negative or not significant coefficients were frequently obtained, especially true in the case of the shallower EIAs -NRPTAs and PTAs. However, those results could lead to misleading interpretations, as Tables 3 and 4 show that this could be due to sectoral aggregation.

For the shallower EIAs, the positive effects of NRPTAs on trade are found in nonferrous metals (s68), vegetables and fruit (s05), cereals (s04), and leather and footwear (s99) in the current period for Equation (1), and only in sector 05 for Equation (2). This means that the estimated coefficients for Equation (1) may include effects that go beyond the current period. In all the above mentioned sectors, the effects on trade are explained mainly by the IM. The table also shows a long-term effect on trade only in iron and steel (s67), which is also explained by the IM. Road vehicles (s78) and general industrial machinery (s74) show a long-term effect of shallower EIAs, but these cases are explained by the EM.

When regressions are run for the sub-period 1989 2009, similar conclusions are reached, but the effect is lower for sectors 68 and 05 and greater for sectors 04 and 99. It is not surprising that the IM of sectors 04 and 05 , which suppose exports of primary goods, has increased considerably, as these sectors are homogeneous, and then, there is a lower margin for diversification. Nevertheless, it is important to note also that the IM has increased to a greater extent in some industrial manufactures (s68) over the second sub-period (second wave of regionalism), except for the case of sector 99 that has experienced a greater increase of the EM in the long term. This result shows that nonreciprocal EIAs have increased the concentration of the export matrix in LAIA countries among the most traded goods. In sum, the (short-term) main effect was reflected on the intensive margin in the most recent sub-period in non-ferrous metals (s68), vegetables

\footnotetext{
${ }^{17}$ This section includes the results for different sectors and for Equation (1) and (2). We only include the results for the second subperiod; as the estimates for the period 1962 1989, the estimation of a number of coefficients is not allowed due to the lack of enough observations. The full results are available upon request.
} 
and fruit (s05), cereals (s04), and leather and footwear (s99).

Table 4 shows that throughout the period, PTAs have a positive effect on trade in the current period in the case of non-ferrous metals, vegetables and fruit, cereals, and leather. Similar to NRPTAs, the effects are explained by the IM. For the long term, there is evidence of a positive effect on trade only for vegetables and fruit, general industrial machinery and iron and steel; the IM also dominates. In the case of non-ferrous metals and cereals, there is a positive effect on the IM in the long term, but it is compensated with a significant and negative effect on the EM which yields a non-significant effect on the total trade. There is no evidence of a positive effect on the EM, except for electrical machinery (s77) in the current period. Furthermore, there is an additional effect on trade in the current period for electrical machinery and iron and steel when the period 1989 2009 is taken into account. For the same period, there is evidence of a long-run effect on trade for general industrial machinery.

In relation to Table 5 and for the period 1962 2009, there is a positive and significant effect on trade for electrical machinery, non-ferrous metals, vegetables and fruit, cereals, and leather in the current period. For all these sectors, the effect mentioned above is explained by the IM except for electrical machinery and vegetables and fruit, where the EM coefficients are positive and significant but they represent only $30 \%$ of the total increase in trade. For electrical machinery and vegetables and fruit, the effects on trade were maintained in the long term. For example, if a LAIA country engages in FTA, its exports of vegetables and fruit increase by $1074 \%\left(\left(e^{2.463}-1\right) * 100\right)$, and about $50 \%$ of this effect is achieved after ten years. Only with positive and significant long-term effects on trade, we can mention the sector of iron and steel (s67), general industrial machinery (s74), and textiles (s65). In all cases, these effects are explained by the IM.

In the second sub-period, as has been previously found for the case of NRPTAs and PTAs, the positive and significant effects of FTAs are reflected mainly in the IM, excluding the case of sector 67 (iron and steel), which presents a positive and significant effect of the 5-year lag of FTA on the EM. Finally, the obtained results show that the FTAs signed in the Latin American region have not had positive consequences in terms of trade margins in the sector of road vehicles (s78), which, in fact, is the most important sector of the total value of exports from the region as shown in Table B. Another aspect worth mentioning is the positive effect on trade in the current period for iron and steel (s67) and general industrial machinery (s74) when the second sub-period is considered.

Overall, Table 6 shows that CUs (Mercosur and Andean Community) present the most important effects and for a broader number of the selected sectors in the region. 
However, several differences among sectors must be mentioned. First, the coefficients obtained in the current period are much higher in magnitude in almost all of the considered sectors than the coefficients for all goods pooled together. However, sector 78 (road vehicles) presents a considerably lower coefficient than the rest of selected sectors. This might be due to the fact that although this sector has the most important participation of LAIA members, it has shown special conditions that affect trade exchanges. This issue is highly controversial and has been accentuated within Mercosur and, particularly, between Brazil and Argentina over the recent years. Second, CUs have a positive and significant effect on the EM in the current period for the case of sectors 77, 05, 67 and 04 and also for the 5-year lag in the case of 67; surprisingly, two of these sectors (05 and 04) are primary goods and agricultural manufactures. Third, CUs increase the IM in the current period for all sectors. Fourth, the 5-year lag of CUs presents a positive and significant effect on the IM in the case of sectors $77,05,67$, and 65, but the 10-year lag of CUs is only positive and significant on the IM for sectors 77 and 05. With respect to the sub-period 1989 2009, as Latin American CUs were signed in the 1990's, the results obtained throughout the period are explained by the evolution of the most recent wave of regionalism. However, the obtained results show that it is important to take into account a long-time period in order to analyze differential timing and test whether positive effects are more persistent over time in trade margins.

Concerning specific sectors, and in line with results obtained in previous research (Baier et al. 2011 and 2014, Florensa et al. 2013 and 2014), Customs Unions show more significant effect than partial trade agreements. Our results show that in the case of sector 99 (leather, leather manufactures, and footwear), the strongest positive effects on trade margins are for CUs, shown in Table 6 on the IM, but only in the current period. On the other hand, the NRPTAs have fostered growth of this type of industrial manufactures (which represent $1.5 \%$ of the value of exports from LAIA) to a greater extent in the EM in the long term as shown in Table 3. 
Table 3. Effects of NRPTAs on trade

\begin{tabular}{|c|c|c|c|c|c|c|c|}
\hline & & \multicolumn{3}{|c|}{$1962 \sim 2009$} & \multicolumn{3}{|c|}{ 1989 2009 } \\
\hline & & TRADE(1) & $\operatorname{EM}(2)$ & $\operatorname{IM}(3)$ & TRADE (4) & EM (5) & $\operatorname{IM}(6)$ \\
\hline \multirow[t]{4}{*}{ All sectors } & NRPTA- Equation (1) & $-0.288 * * *$ & -0.027 & $-0.263 * * *$ & -0.068 & -0.059 & -0.011 \\
\hline & NRPTA- Equation (2) & $-0.232 * *$ & -0.126 & -0.106 & -0.040 & 0.049 & -0.089 \\
\hline & L5.NRPTA & -0.073 & -0.132 & 0.059 & 0.056 & -0.011 & 0.067 \\
\hline & L10.NRPTA & -0.064 & 0.028 & -0.091 & -0.263 & 0.015 & -0.277 \\
\hline \multirow[t]{4}{*}{ Sector 78} & NRPTA- Equation (1) & $-1.248^{* * *}$ & $-0.335^{* * *}$ & $-0.911 * * *$ & $-0.991 * * *$ & $-0.615 * * *$ & -0.375 \\
\hline & NRPTA- Equation (2) & $-1.681 * * *$ & $-0.604 * * *$ & $-1.077 * * *$ & $-1.806^{* * *}$ & $-0.558^{* *}$ & $-1.248^{* * *}$ \\
\hline & L5.NRPTA & 0.108 & -0.280 & 0.388 & 0.098 & -0.273 & 0.371 \\
\hline & L10.NRPTA & -0.369 & $0.660 * *$ & $-1.029 *$ & -0.767 & 0.330 & $-1.098^{*}$ \\
\hline \multirow[t]{4}{*}{ Sector 77} & NRPTA- Equation (1) & 0.132 & $0.270 * * *$ & -0.136 & $0.376^{*}$ & 0.165 & 0.213 \\
\hline & NRPTA- Equation (2) & -0.155 & 0.223 & -0.378 & 0.085 & 0.054 & 0.031 \\
\hline & L5.NRPTA & 0.325 & -0.104 & 0.430 & 0.370 & $-0.222^{*}$ & $0.592 * *$ \\
\hline & L10.NRPTA & 0.590 & -0.005 & 0.595 & 0.638 & -0.243 & $0.881^{* *}$ \\
\hline \multirow[t]{4}{*}{ Sector 68} & NRPTA- Equation (1) & $0.532 * *$ & -0.135 & $0.668 * * *$ & $0.475^{*}$ & $-0.361 * * *$ & $0.836^{* * *}$ \\
\hline & NRPTA- Equation (2) & 0.187 & $-0.296^{*}$ & 0.482 & -0.122 & $-0.599 * * *$ & 0.477 \\
\hline & L5.NRPTA & $-0.864 * *$ & $-0.455^{* *}$ & -0.409 & $-0.735^{*}$ & $-0.545^{* * *}$ & -0.189 \\
\hline & L10.NRPTA & 0.138 & 0.298 & -0.160 & 0.104 & -0.123 & 0.227 \\
\hline \multirow[t]{4}{*}{ Sector 05} & NRPTA- Equation (1) & $0.922 * * *$ & $0.386^{* * *}$ & $0.536^{* * *}$ & $0.624 * * *$ & 0.039 & $0.587 * * *$ \\
\hline & NRPTA- Equation (2) & $0.722 * * *$ & -0.039 & $0.761 * * *$ & $0.429 *$ & $-0.320 * *$ & $0.749 * * *$ \\
\hline & L5.NRPTA & -0.085 & 0.047 & -0.132 & -0.215 & $-0.302 * *$ & 0.087 \\
\hline & L10.NRPTA & 0.390 & -0.071 & 0.461 & -0.249 & $-0.397^{*}$ & 0.148 \\
\hline \multirow[t]{4}{*}{ Sector 67} & NRPTA- Equation (1) & -0.274 & -0.129 & -0.145 & 0.319 & 0.018 & 0.302 \\
\hline & NRPTA- Equation (2) & $-0.651 *$ & $-0.467 * *$ & -0.183 & 0.023 & $-0.569 * * *$ & 0.592 \\
\hline & L5.NRPTA & $1.231^{* * *}$ & 0.206 & $1.025^{* * *}$ & $1.432 * * *$ & 0.290 & $1.141^{* * *}$ \\
\hline & L10.NRPTA & 0.624 & 0.42 & 0.204 & -0.304 & -0.150 & -0.154 \\
\hline \multirow[t]{4}{*}{ Sector 74} & NRPTA- Equation (1) & $-0.585^{* * *}$ & $-0.328 * * *$ & $-0.258 *$ & -0.002 & $-0.213 *$ & 0.210 \\
\hline & NRPTA- Equation (2) & $-0.412 *$ & $-0.343 * * *$ & -0.069 & -0.329 & $-0.357 * * *$ & 0.027 \\
\hline & L5.NRPTA & -0.031 & 0.017 & -0.048 & 0.288 & 0.002 & 0.286 \\
\hline & L10.NRPTA & 0.470 & $0.516^{* * *}$ & -0.047 & 0.012 & 0.026 & -0.014 \\
\hline \multirow[t]{4}{*}{ Sector 04} & NRPTA- Equation (1) & $1.780^{* * *}$ & 0.154 & $1.628^{* * *}$ & $1.852 * * *$ & $0.634 * * *$ & $1.218^{* * *}$ \\
\hline & NRPTA- Equation (2) & $-2.580^{* * *}$ & $-1.960 * * *$ & -0.621 & -0.615 & 0.104 & -0.719 \\
\hline & L5.NRPTA & -0.369 & -0.419 & 0.051 & -0.530 & -0.076 & -0.454 \\
\hline & L10.NRPTA & -0.364 & 0.409 & -0.774 & 0.280 & -0.285 & 0.565 \\
\hline \multirow[t]{4}{*}{ Sector 65} & NRPTA- Equation (1) & $-0.398^{* * *}$ & $-0.218^{* *}$ & -0.182 & $-0.573^{* * *}$ & $-0.241^{*}$ & $-0.334^{*}$ \\
\hline & NRPTA- Equation (2) & $-0.516^{* *}$ & $-0.424 * * *$ & -0.092 & $-0.536^{* *}$ & $-0.715^{* * *}$ & 0.179 \\
\hline & L5.NRPTA & 0.063 & 0.221 & -0.158 & $-0.445^{*}$ & 0.189 & $-0.633^{* *}$ \\
\hline & L10.NRPTA & $-0.852^{* * *}$ & 0.018 & $-0.870^{* * *}$ & $-0.882 * *$ & -0.335 & -0.548 \\
\hline \multirow[t]{4}{*}{ Sector 99} & NRPTA- Equation (1) & $0.388^{* *}$ & -0.110 & $0.498^{* *}$ & $0.553^{* *}$ & 0.132 & 0.421 \\
\hline & NRPTA- Equation (2) & -0.160 & 0.114 & -0.274 & $1.379^{* *}$ & 0.090 & $1.290^{*}$ \\
\hline & L5.NRPTA & -0.416 & -0.081 & -0.335 & -0.143 & 0.227 & -0.370 \\
\hline & L10.NRPTA & -0.207 & 0.283 & -0.490 & 0.053 & $1.056 * * *$ & $-1.002 *$ \\
\hline
\end{tabular}

(Notes) *** denote statistically significant at $1 \%$,

** denote statistically significant at $5 \%$,

* denote statistically significant at $10 \%$. 


\section{Table 4. Effects of PTAs on trade}

\begin{tabular}{|c|c|c|c|c|c|c|c|}
\hline & \multicolumn{3}{|c|}{ 1962 2009 } & \multicolumn{3}{|c|}{ 1989 2009 } \\
\hline & & TRADE(1) & $\mathrm{EM}(2)$ & $\operatorname{IM}(3)$ & TRADE (4) & EM (5) & $\operatorname{IM}(6)$ \\
\hline \multirow[t]{4}{*}{ All sectors } & PTA- Equation (1) & -0.007 & $0.123 * *$ & $-0.130 *$ & $0.191 *$ & $-0.148^{*}$ & $0.340 * * *$ \\
\hline & PTA- Equation (2) & -0.078 & -0.111 & 0.033 & 0.323 & 0.176 & 0.147 \\
\hline & L5.PTA & -0.064 & $-0.136^{*}$ & 0.072 & 0.079 & -0.027 & 0.107 \\
\hline & L10.PTA & 0.076 & 0.069 & 0.006 & 0.088 & -0.297 & $0.385^{* *}$ \\
\hline \multirow[t]{4}{*}{ Sector 78} & PTA- Equation (1) & $-0.610 * * *$ & 0.047 & $-0.657 * * *$ & -0.466 & $-0.347 * *$ & -0.120 \\
\hline & PTA- Equation (2) & $-1.083^{* * *}$ & -0.322 & $-0.761^{*}$ & -0.739 & -0.077 & -0.662 \\
\hline & L5.PTA & 0.187 & 0.033 & 0.154 & 0.083 & -0.173 & 0.255 \\
\hline & L10.PTA & -0.411 & 0.122 & -0.533 & -0.730 & 0.381 & $-1.112^{* *}$ \\
\hline \multirow[t]{4}{*}{ Sector 77} & PTA- Equation (1) & 0.208 & $0.146^{* *}$ & 0.063 & $0.389^{*}$ & $-0.268 * *$ & $0.658 * * *$ \\
\hline & PTA- Equation (2) & $-0.562 * *$ & -0.127 & $-0.435^{*}$ & 0.044 & 0.009 & 0.035 \\
\hline & L5.PTA & 0.316 & -0.062 & $0.378^{*}$ & 0.277 & -0.058 & 0.336 \\
\hline & L10.PTA & -0.060 & $-0.233 * *$ & 0.173 & 0.012 & $-0.322 * *$ & 0.335 \\
\hline \multirow[t]{4}{*}{ Sector 68} & PTA- Equation (1) & $0.799 * * *$ & -0.126 & $0.925 * * *$ & $0.782 * * *$ & $-0.316^{* *}$ & $1.097 * * *$ \\
\hline & PTA- Equation (2) & -0.028 & -0.129 & 0.101 & -0.397 & $-0.345^{*}$ & -0.052 \\
\hline & L5.PTA & 0.277 & $-0.454 * *$ & $0.731 * *$ & 0.407 & $-0.542 * *$ & $0.950 * *$ \\
\hline & L10.PTA & $-0.606^{*}$ & $-0.338^{*}$ & -0.268 & -0.832 & $-0.678^{*}$ & -0.154 \\
\hline \multirow[t]{4}{*}{ Sector 05} & PTA- Equation (1) & $1.015^{* * *}$ & -0.002 & $1.021 * * *$ & $0.957 * * *$ & -0.157 & $1.118 * * *$ \\
\hline & PTA- Equation (2) & $0.968 * * *$ & -0.197 & $1.165^{* * *}$ & $1.058^{* * *}$ & -0.184 & $1.242 * * *$ \\
\hline & L5.PTA & -0.177 & -0.236 & 0.060 & -0.086 & $-0.447 * * *$ & 0.361 \\
\hline & L10.PTA & $1.037 * * *$ & -0.270 & $1.306^{* * *}$ & 0.335 & $-0.466^{*}$ & 0.801 \\
\hline \multirow[t]{4}{*}{ Sector 67} & PTA- Equation (1) & 0.154 & $-0.188^{*}$ & $0.342^{*}$ & $0.431^{*}$ & -0.166 & $0.596^{* *}$ \\
\hline & PTA- Equation (2) & $-0.795^{* *}$ & $-0.511 * * *$ & -0.284 & 0.096 & $-0.696^{* * *}$ & $0.792 *$ \\
\hline & L5.PTA & $1.150 * * *$ & $0.292^{*}$ & $0.858 * * *$ & $1.451^{* * *}$ & $0.393^{* *}$ & $1.057 * * *$ \\
\hline & L10.PTA & 0.267 & 0.029 & 0.237 & -0.316 & -0.316 & 0.000 \\
\hline \multirow[t]{4}{*}{ Sector 74} & PTA- Equation (1) & 0.034 & $-0.214^{* * *}$ & $0.249^{* *}$ & $0.357^{*}$ & $-0.198^{*}$ & $0.557 * * *$ \\
\hline & PTA- Equation (2) & -0.234 & $-0.265^{* *}$ & 0.031 & 0.203 & -0.076 & 0.279 \\
\hline & L5.PTA & 0.126 & -0.059 & 0.185 & $0.462 *$ & -0.019 & $0.481^{* *}$ \\
\hline & L10.PTA & $0.462 * * *$ & 0.008 & $0.454 * * *$ & 0.069 & 0.112 & -0.043 \\
\hline \multirow[t]{4}{*}{ Sector 04} & PTA- Equation (1) & $1.303 * * *$ & 0.068 & $1.234 * * *$ & $1.456^{* * *}$ & 0.076 & $1.375 * * *$ \\
\hline & PTA- Equation (2) & $-2.116^{* * *}$ & $-2.083 * * *$ & -0.032 & -0.325 & -0.184 & -0.141 \\
\hline & L5.PTA & 0.115 & $-0.915^{* * *}$ & $1.031 * *$ & 0.015 & $-0.598^{*}$ & 0.613 \\
\hline & L10.PTA & $-1.116^{* *}$ & 0.002 & $-1.117 * *$ & 0.052 & -0.110 & 0.162 \\
\hline \multirow[t]{4}{*}{ Sector 65} & PTA- Equation (1) & $-0.437 * * *$ & $-0.218^{* *}$ & $-0.218^{*}$ & -0.013 & $-0.256^{* *}$ & 0.245 \\
\hline & PTA- Equation (2) & $-0.544 * *$ & $-0.498^{* * *}$ & -0.047 & -0.057 & $-0.628 * * *$ & $0.571^{* *}$ \\
\hline & L5.PTA & $0.554^{* *}$ & $0.303 * *$ & 0.250 & -0.056 & 0.251 & -0.308 \\
\hline & L10.PTA & $-0.894 * * *$ & 0.071 & $-0.965 * * *$ & -0.334 & $-0.654 * * *$ & 0.320 \\
\hline \multirow[t]{4}{*}{ Sector 99} & PTA- Equation (1) & $0.552 * *$ & 0.021 & $0.531 * * *$ & $0.406^{*}$ & 0.084 & 0.322 \\
\hline & PTA- Equation (2) & -0.308 & -0.014 & -0.295 & 0.798 & -0.048 & 0.846 \\
\hline & L5.PTA & -0.331 & $-0.544 * *$ & 0.213 & 0.033 & -0.494 & 0.527 \\
\hline & L10.PTA & 0.291 & -0.086 & 0.377 & 0.223 & 0.541 & -0.318 \\
\hline
\end{tabular}

(Notes) $* * *$ denote statistically significant at $1 \%$,

** denote statistically significant at $5 \%$,

* denote statistically significant at $10 \%$. 
Table 5. Effects of FTAs on trade

\begin{tabular}{|c|c|c|c|c|c|c|c|}
\hline & \multicolumn{3}{|c|}{$1962 \sim 2009$} & \multicolumn{3}{|c|}{ 1989 2009 } \\
\hline & & TRADE(1) & $\operatorname{EM}(2)$ & $\operatorname{IM}(3)$ & TRADE (4) & EM (5) & $\mathrm{IM}(6)$ \\
\hline \multirow[t]{4}{*}{ All sectors } & FTA- Equation (1) & $0.313 * * *$ & $0.185 * *$ & 0.129 & $0.386 * * *$ & 0.002 & $0.384 * * *$ \\
\hline & FTA- Equation (2) & $0.181 *$ & 0.055 & 0.126 & $0.355^{* *}$ & 0.160 & 0.195 \\
\hline & L5.FTA & -0.077 & $-0.399 * * *$ & $0.322 * * *$ & 0.105 & -0.206 & $0.311 * *$ \\
\hline & L10.FTA & 0.237 & -0.050 & $0.287^{* *}$ & 0.123 & $-0.341^{*}$ & $0.464 * *$ \\
\hline \multirow[t]{4}{*}{ Sector 78} & FTA- Equation (1) & $-0.786^{* * *}$ & 0.025 & $-0.812 * * *$ & -0.422 & -0.156 & -0.267 \\
\hline & FTA- Equation (2) & $-1.287 * * *$ & -0.300 & $-0.987 * * *$ & $-0.876^{* *}$ & 0.002 & $-0.877 * *$ \\
\hline & L5.FTA & -0.320 & -0.245 & -0.075 & -0.313 & -0.298 & -0.014 \\
\hline & L10.FTA & -0.482 & 0.045 & -0.527 & -0.834 & 0.276 & $-1.110^{* *}$ \\
\hline \multirow[t]{4}{*}{ Sector 77} & FTA- Equation (1) & $0.478^{* * *}$ & $0.139^{*}$ & $0.340 * *$ & $0.450 * *$ & -0.154 & $0.604 * * *$ \\
\hline & FTA- Equation (2) & -0.129 & 0.031 & -0.160 & -0.018 & 0.020 & -0.039 \\
\hline & L5.FTA & $0.418^{*}$ & -0.188 & $0.606^{* * *}$ & $0.353^{*}$ & $-0.205^{*}$ & $0.558^{* * *}$ \\
\hline & L10.FTA & 0.153 & $-0.245^{* *}$ & $0.397^{*}$ & 0.014 & $-0.347 * *$ & 0.361 \\
\hline \multirow[t]{4}{*}{ Sector 68} & FTA- Equation (1) & $0.749 * * *$ & -0.114 & $0.863 * * *$ & $0.796^{* * *}$ & $-0.304 * *$ & $1.100 * * *$ \\
\hline & FTA- Equation (2) & 0.273 & -0.165 & 0.438 & 0.083 & $-0.297^{*}$ & 0.380 \\
\hline & L5.FTA & -0.063 & $-0.379 * *$ & 0.316 & 0.045 & $-0.445^{* *}$ & 0.491 \\
\hline & L10.FTA & -0.350 & $-0.399^{* *}$ & 0.049 & -0.468 & $-0.641 * *$ & 0.173 \\
\hline \multirow[t]{4}{*}{ Sector 05} & FTA- Equation (1) & $1.284 * * *$ & $0.369^{* * *}$ & $0.917 * * *$ & $1.062 * * *$ & 0.152 & $0.913 * * *$ \\
\hline & FTA- Equation (2) & $1.212 * * *$ & 0.095 & 1.117 & $1.009^{* * *}$ & -0.090 & $1.099^{* * *}$ \\
\hline & L5.FTA & 0.148 & 0.086 & $0.062 * * *$ & -0.108 & -0.209 & 0.102 \\
\hline & L10.FTA & $1.251 * * *$ & $-0.415 * * *$ & $1.666 * * *$ & 0.472 & $-0.628 * *$ & $1.100 * *$ \\
\hline \multirow[t]{4}{*}{ Sector 67} & FTA- Equation (1) & 0.293 & -0.046 & $0.339^{*}$ & $0.593 * *$ & 0.103 & $0.490 * *$ \\
\hline & FTA- Equation (2) & -0.482 & $-0.542 * * *$ & 0.06 & 0.237 & $-0.611 * * *$ & $0.848 * *$ \\
\hline & L5.FTA & $1.233^{* * *}$ & 0.214 & $1.019^{* * *}$ & $1.465^{* * *}$ & $0.303^{*}$ & $1.163^{* * *}$ \\
\hline & L10.FTA & 0.431 & -0.022 & 0.452 & -0.118 & -0.314 & 0.197 \\
\hline \multirow[t]{4}{*}{ Sector 74} & FTA- Equation (1) & 0.137 & $-0.130 * *$ & $0.267 * *$ & $0.434 * *$ & -0.095 & $0.530 * * *$ \\
\hline & FTA- Equation (2) & -0.047 & $-0.253 * *$ & 0.206 & 0.253 & -0.149 & $0.402 *$ \\
\hline & L5.FTA & 0.127 & -0.115 & 0.242 & 0.291 & -0.051 & $0.342 *$ \\
\hline & L10.FTA & $0.401 *$ & -0.080 & $0.481 * *$ & -0.038 & -0.029 & -0.010 \\
\hline \multirow[t]{4}{*}{ Sector 04} & FTA- Equation (1) & $0.983^{* * *}$ & 0.033 & $0.952 * * *$ & $1.172 * * *$ & 0.044 & $1.128^{* * *}$ \\
\hline & FTA- Equation (2) & $-2.475^{* * *}$ & $-2.257 * * *$ & -0.218 & -0.491 & -0.406 & -0.085 \\
\hline & L5.FTA & -0.518 & $-0.941 * * *$ & 0.423 & 0.316 & -0.327 & 0.643 \\
\hline & L10.FTA & $-1.249^{* *}$ & -0.416 & -0.833 & 0.094 & -0.417 & 0.511 \\
\hline \multirow[t]{4}{*}{ Sector 65} & FTA- Equation (1) & -0.216 & $-0.218^{* *}$ & 0.003 & -0.011 & -0.030 & 0.022 \\
\hline & FTA- Equation (2) & $-0.348^{*}$ & $-0.370 * * *$ & 0.022 & -0.017 & $-0.389 * * *$ & 0.373 \\
\hline & L5.FTA & $0.411^{* *}$ & 0.005 & $0.406^{*}$ & -0.030 & 0.101 & -0.131 \\
\hline & L10.FTA & $-0.372 *$ & -0.031 & -0.341 & -0.115 & $-0.579 * *$ & 0.464 \\
\hline \multirow[t]{4}{*}{ Sector 99} & FTA- Equation (1) & $0.877 * * *$ & 0.011 & $0.866 * * *$ & $0.439^{*}$ & 0.096 & 0.342 \\
\hline & FTA- Equation (2) & 0.031 & -0.132 & 0.163 & $1.144 * *$ & -0.123 & $1.267 *$ \\
\hline & L5.FTA & $-0.539^{*}$ & -0.296 & -0.243 & -0.440 & 0.046 & -0.486 \\
\hline & L10.FTA & 0.509 & -0.231 & $0.741 * *$ & 0.406 & 0.485 & -0.079 \\
\hline
\end{tabular}

(Notes) $* * *$ denote statistically significant at $1 \%$,

** denote statistically significant at $5 \%$,

* denote statistically significant at $10 \%$. 


\section{Table 6. Effects of CUs on trade}

\begin{tabular}{|c|c|c|c|c|c|c|c|}
\hline & \multicolumn{3}{|c|}{$1962 \sim 2009$} & \multicolumn{3}{|c|}{ 1989 2009 } \\
\hline & & TRADE(1) & $\operatorname{EM}(2)$ & $\operatorname{IM}(3)$ & TRADE (4) & EM (5) & IM (6) \\
\hline \multirow[t]{4}{*}{ All sectors } & \multirow{4}{*}{$\begin{array}{l}\text { CU- Equation (1) } \\
\text { CU- Equation (2) } \\
\text { L5.CU } \\
\text { L10.CU }\end{array}$} & $0.914 * * *$ & $0.250 * * *$ & $0.663 * * *$ & $0.778 * * *$ & -0.058 & $0.836 * * *$ \\
\hline & & $0.598^{* * *}$ & $0.342 * * *$ & $0.256^{*}$ & 0.260 & 0.039 & 0.221 \\
\hline & & 0.043 & $-0.442 * * *$ & $0.485^{* * *}$ & 0.212 & -0.308 & $0.520 * * *$ \\
\hline & & 0.101 & -0.088 & 0.190 & -0.064 & $-0.524 * * *$ & $0.460 * *$ \\
\hline \multirow[t]{4}{*}{ Sector 78} & \multirow{4}{*}{$\begin{array}{l}\text { CU- Equation (1) } \\
\text { CU- Equation (2) } \\
\text { L5.CU } \\
\text { L10.CU }\end{array}$} & $0.679 * * *$ & 0.059 & $0.620 * * *$ & $0.657 * *$ & $-0.378^{*}$ & $1.034 * * *$ \\
\hline & & $1.167 * *$ & 0.183 & $0.985^{* *}$ & 0.117 & 0.630 & -0.513 \\
\hline & & -0.136 & $-0.653^{*}$ & 0.517 & -0.263 & $-0.863 * * *$ & 0.600 \\
\hline & & $-0.966^{*}$ & 0.049 & $-1.015^{* *}$ & $-1.330 * *$ & 0.255 & $-1.584 * * *$ \\
\hline \multirow[t]{4}{*}{ Sector 77} & \multirow{4}{*}{$\begin{array}{l}\text { CU- Equation (1) } \\
\text { CU- Equation (2) } \\
\text { L5.CU } \\
\text { L10.CU }\end{array}$} & $1.435 * * *$ & $0.224 * *$ & $1.213^{* * *}$ & $1.616^{* * *}$ & -0.235 & $1.852 * * *$ \\
\hline & & 0.145 & $0.326^{*}$ & -0.181 & -0.299 & $0.881 * * *$ & $-1.181^{*}$ \\
\hline & & $0.835^{* *}$ & $-0.653 * * *$ & $1.488^{* * *}$ & $0.932 * * *$ & $-0.717 * * *$ & $1.648^{* * *}$ \\
\hline & & 0.166 & $-0.379 * *$ & $0.545^{* *}$ & -0.095 & $-0.575^{* * *}$ & 0.480 \\
\hline \multirow[t]{4}{*}{ Sector 68} & \multirow{4}{*}{$\begin{array}{l}\text { CU- Equation (1) } \\
\text { CU- Equation (2) } \\
\text { L5.CU } \\
\text { L10.CU }\end{array}$} & $1.540 * * *$ & 0.041 & $1.498 * * *$ & $1.395 * * *$ & -0.130 & $1.525 * * *$ \\
\hline & & 0.397 & -0.145 & 0.542 & 0.200 & -0.413 & 0.613 \\
\hline & & 0.046 & -0.303 & 0.348 & 0.137 & $-0.422 *$ & 0.558 \\
\hline & & -0.313 & $-0.470^{* *}$ & 0.157 & -0.421 & $-0.723^{* *}$ & 0.302 \\
\hline \multirow[t]{4}{*}{ Sector 05} & \multirow{4}{*}{$\begin{array}{l}\text { CU- Equation (1) } \\
\text { CU- Equation (2) } \\
\text { L5.CU } \\
\text { L10.CU }\end{array}$} & $1.644 * * *$ & $0.570 * * *$ & $1.078^{* * *}$ & $1.074 * * *$ & $0.225^{*}$ & $0.853^{* * *}$ \\
\hline & & $0.958^{* * *}$ & 0.116 & $0.841 * *$ & $0.883^{*}$ & -0.030 & $0.912 *$ \\
\hline & & 0.535 & -0.245 & $0.781^{*}$ & 0.447 & $-0.528^{* * *}$ & $0.974 * * *$ \\
\hline & & 0.754 & $-0.475^{* * *}$ & $1.229 * * *$ & 0.002 & $-0.756 * * *$ & 0.758 \\
\hline \multirow[t]{4}{*}{ Sector 67} & \multirow{4}{*}{$\begin{array}{l}\text { CU- Equation (1) } \\
\text { CU- Equation (2) } \\
\text { L5.CU } \\
\text { L10.CU }\end{array}$} & $1.704 * * *$ & $0.240^{*}$ & $1.464 * * *$ & $2.044 * * *$ & $0.405 * *$ & $1.638 * * *$ \\
\hline & & -0.099 & $-0.948 * * *$ & $0.849 *$ & 0.087 & $-0.944 * *$ & 1.031 \\
\hline & & $1.558^{* * *}$ & $0.505^{* *}$ & $1.053^{* *}$ & $1.809 * * *$ & $0.566^{* *}$ & $1.243^{* *}$ \\
\hline & & 0.412 & -0.054 & 0.466 & -0.256 & -0.331 & 0.075 \\
\hline \multirow[t]{4}{*}{ Sector 74} & \multirow{4}{*}{$\begin{array}{l}\text { CU- Equation (1) } \\
\text { CU- Equation (2) } \\
\text { L5.CU } \\
\text { L10.CU }\end{array}$} & $0.318^{*}$ & -0.066 & $0.384 * *$ & $0.963 * * *$ & -0.189 & $1.154 * * *$ \\
\hline & & 0.019 & -0.156 & 0.175 & -0.094 & -0.169 & 0.075 \\
\hline & & 0.113 & $-0.286^{*}$ & 0.398 & 0.406 & $-0.266^{* *}$ & $0.672 * * *$ \\
\hline & & 0.213 & -0.075 & 0.288 & -0.257 & -0.080 & -0.177 \\
\hline \multirow[t]{4}{*}{ Sector 04} & \multirow{4}{*}{$\begin{array}{l}\text { CU- Equation (1) } \\
\text { CU- Equation (2) } \\
\text { L5.CU } \\
\text { L10.CU }\end{array}$} & $2.671 * * *$ & $0.605 * * *$ & $2.066^{* * *}$ & $2.692 * * *$ & $0.387^{*}$ & $2.305 * * *$ \\
\hline & & -0.598 & $-1.261^{*}$ & 0.662 & -0.226 & 0.966 & -1.192 \\
\hline & & 0.231 & -0.701 & 0.932 & $0.972 *$ & -0.192 & $1.164 *$ \\
\hline & & $-1.524 * * *$ & -0.601 & -0.923 & -0.260 & -0.696 & 0.436 \\
\hline \multirow[t]{4}{*}{ Sector 65} & \multirow{4}{*}{$\begin{array}{l}\text { CU- Equation (1) } \\
\text { CU- Equation (2) } \\
\text { L5.CU } \\
\text { L10.CU }\end{array}$} & $0.974 * * *$ & 0.039 & $0.936^{* * *}$ & $1.026^{* * *}$ & -0.047 & $1.075^{* * *}$ \\
\hline & & 0.247 & -0.151 & 0.398 & 0.063 & $-1.022 * * *$ & $1.085^{* *}$ \\
\hline & & $0.743^{* * *}$ & -0.103 & $0.846^{* * *}$ & 0.153 & -0.170 & 0.322 \\
\hline & & $-0.609 * *$ & -0.168 & $-0.441^{*}$ & -0.231 & $-0.753 * * *$ & 0.521 \\
\hline \multirow[t]{4}{*}{ Sector 99} & \multirow{4}{*}{$\begin{array}{l}\text { CU- Equation (1) } \\
\text { CU- Equation (2) } \\
\text { L5.CU } \\
\text { L10.CU }\end{array}$} & $1.691 * * *$ & 0.147 & $1.544 * * *$ & $1.101 * * *$ & -0.060 & $1.161 * * *$ \\
\hline & & 0.798 & 0.339 & 0.460 & 1.174 & -0.285 & 1.459 \\
\hline & & 0.084 & $-0.669^{*}$ & 0.753 & 0.502 & -0.566 & 1.068 \\
\hline & & 0.137 & -0.350 & 0.487 & 0.162 & 0.331 & -0.169 \\
\hline
\end{tabular}

(Notes) $* * *$ denote statistically significant at $1 \%$,

** denote statistically significant at $5 \%$,

* denote statistically significant at $10 \%$. 


\section{Conclusion}

In order to analyze the effects of economic integration in Latin America on the extensive and intensive margins of trade, we follow the methodology introduced in Baier et al. (2011). The analysis is performed for all members of Latin American Integration Association (LAIA) and their bilateral exports to a large group of trading partners over the period 1962 2009; also, two different sub-periods, 1962 1989 and 1989 2009, are analyzed.

Given the economic instability that characterizes the group of the selected exporting countries, different periods of time have been taken into account in order to confirm whether the results over 1962 2009 can be generalized, or dissimilar effects exist according to the period under consideration. Initially, this long time period allowed us to determine whether different effects on trade margins might arise and, then, with the analysis for the two sub-periods, we answered whether the effect of economic integration on trade margins is period-sensitive. In particular, our interest lied in the period after the extension of trade integration agreements and the deepening of the liberalization process in the region. In addition, we distinguished the effects on different sectors selected that represent an average of one-third of the exports in value from LAIA countries over the period 1962 2009.

The obtained results show that the effect of economic integration is both time- and period-sensitive. For the new regionalism, the main positive effects were reflected in the intensive margin for all different types of agreements, not only for primary goods and agricultural manufactures but also for industrial manufactures. Moreover, in line with previous research, we find that deeper economic integration agreements have a greater effect on international trade.

The obtained results also show that it is important to take into account a long time period in order to analyze differential timing and test whether positive effects are more persistent over time in trade margins. In this respect, the results show that the deepest Economic Integration Agreements (EIAs), that is the Customs Union (CU), appear to promote the development of industrial manufactures in the long run, especially in the intensive margin. Therefore, we provide partial evidence in favour of the trade gains of EIAs in Latin America.

Finally, an increase in the Intensive Margins (IM) or in the Extensive Margins (EM) can have a different impact in terms of the structure of production and development 
in LAIA countries depending on the sector. For example, an increase of the intensive margin in a sector such as non-ferrous metals has necessarily other implications for the structure of production than an increase in the sector of vegetables and fruit. Therefore, the findings obtained in this paper have important policy implications, in particular, for policies that target economic development. With regard to two strategic sectors in the region, the obtained results show that the Free Trade Agreements (FTAs) signed have not had positive consequences in terms of trade margins in the division of road vehicles. For leather, leather manufactures, and footwear, the strongest positive effect on trade margins are for CUs on the IM, but only in the current period. Otherwise, the Nonreciprocal Preferential Trade Agreement (NRPTA) have fostered growth of this type of industrial manufactures to a greater extent in the EM in the long term.

In this paper, we present the following policy implications with regards to Latin American integration:

- Main results are that the main effects on trade flows occur in the long-term. Also, deeper economic integration agreements have a greater effect on international trade. The effect of economic integration on trade margins is both time and period sensitive. Therefore, it is difficult for the economies in the region to commit into strong objectives due to political and economic instability.

- Changes in the alignment within groups of countries should also be considered (see for example the case of the alignment of Argentina and Ecuador with the Bolivarian strategy).

- Signed agreements might not be respected in the long-run, or might be overridden by new agreements.

- The utility of the recent wave of new agreements in Latin America, which increases the complexity in economic integration in the region, should be taken into account. In fact, it could be argued that to sign a high number of overlapping agreements when the main consequence might be to continue exporting (a higher amount of) the same goods (increase in the intensive margin) is not the best strategy to follow.

- It is worth mentioning that an increase in the extensive margin or in the intensive margin can have a different impact in terms of the structure of production and development depending on the sector: it is not the same to increase exports in primary goods and agricultural manufactures than to increase exports in industrial manufactures.

- Obtained results help decisions about the reconfiguration of the Latin American 
region.

Received 20 December 2013, Revised 19 November 2014, Accepted 21 April 2015

\section{References}

Abraham, Filip, Zuzanna Studnicka, and Jan Van Hove. "How distinct is distance?." Paper presented in the thirteenth annual conference of The European Trade Study Group, Copenhagen, September 8-10, (2011).

Baier, Scott L., Jeffrey H. Bergstrand, and Peter Egger. "The New Regionalism: Causes and Consequences." Paper presented at the third Inter-American Development Bank and CEPII Conference, Washington D. C., February 9-10, (2006).

Baier, Scott L., Jeffrey H. Bergstrand, and Michael Feng. "Economic Integration Agreements and the Margins of International Trade." University of Notre Dame, mimeo. Available at IDEAS. https://ideas.repec.org/e/pbe138.html. (Version October 20, (2011); accessed April 22, 2012).

Baier, Scott L., Jeffrey H. Bergstrand, and Michael Feng. "Economic integration agreements and the margins of international trade." Journal of International Economics 93 (2014): 339-350.

Baier, Scott L., and Jeffrey H. Bergstrand: "Do free trade agreements actually increase members' international trade?." Journal of International Economics 71 (2007): 72-95.

Bensassi, Sami, Laura Márquez-Ramos, and Inmaculada Martínez-Zarzoso. "Economic Integration and the Two Margins of Trade: The Impact of the Barcelona Process on North African Countries' Exports.” Journal of African Economies 21 (2012): 228-265.

Eichengreen, Barry, and Jeffrey A. Frankel. "Economic Regionalism: Evidence from Two 20th Century Episodes." The North American Journal of Economics and Finance 6 (1995): 89-106.

Feenstra, Robert C., Robert E. Lipsey, Haiyan Deng, Alyson C. Ma, and Hengyong Mo. “World Trade Flows: 1962-2000.” NBER Working Paper 11040 (2005). 
Florensa, Luis M., Laura Márquez-Ramos, Inmaculada Martínez-Zarzoso, and María Luisa Recalde. "Trade in intermediate goods and regional production networks." An application for Latin America. Paper presented in the thirteenth annual conference of The European Trade Study Group, Copenhagen, September 8-10, (2011).

Florensa, Luis M., Laura Márquez-Ramos, María Luisa Recalde, and María Victoria Barone. "Acuerdos de integración económica en Latinoamérica: Efectos sobre los márgenes de comercio.” Revista de Economía 20, N 1 (2013): 71-107.

Florensa, Luis M., Laura Márquez-Ramos, María Luisa Recalde, and María Victoria Barone. M. V. "Does economic integration increase trade margins? Empirical evidence from LAIAs countries." Universitat Jaume I Working Papers. Working Paper 2014/05 (2014).

Florensa, Luis M., Laura Márquez-Ramos, and María Luisa Recalde. "The effect of economic integration and institutional quality of trade agreements on trade margins: evidence for Latin America." Review of World Economics 151(2015a): 329-351.

Florensa, Luis M., Laura Márquez-Ramos, Inmaculada Martínez-Zarzoso, and María Luisa Recalde. "Regional versus global production networks: where does Latin America stand?." Applied Economics (2015b): 1-19. Accessed March 23, 2015. DOI:10.1080/000 36846.2015.1023938.

Frankel, Jeffrey A., Ernesto Stein, and Shang-Jin Wei. "Regional Trading Arrangements: Natural or Supernatural.” American Economic Review 86 (1996): 52-56.

Frankel, J., E. Stein and Shang-Jin Wei. "Open Regionalism in a World of Continental Trade Blocs." IMF Staff Papers 45 (1998): 440-53.

Grugel, Jean B. "New Regionalism and Modes of Governance - Comparing US and EU Strategies in Latin America." European Journal of International Relations 10 (2004): 603-626.

Hillberry, Russell, and Christine McDaniel. "A Decomposition of North American Trade Growth since NAFTA." US International Trade Commission Working Paper. Working Paper 2003-2012 (2003).

Hillberry, Russell, and David Hummels. "Trade Responses to Geographical Frictions: A Decomposition Using Micro-Data.” European Economic Review 52 (2008): 527-50.

Hummels, David, and Peter Klenow. "The Variety and Quality of a Nation`s Exports. 
American Economic Review 95 (2005): 704-723.

Kehoe, Timothy and Kim Ruhl. "How important is the new goods margin in international trade?." Federal Reserve Bank of Minneapolis Staff Reports . Staff Report 324 (2013).

Magee, Christopher S.P. "New Measures of Trade Creation and Trade Diversion." Journal of International Economics 75 (2008): 349-62.

Melitz, Marc J. "The Impact of Trade in Intra-industry Reallocations and Aggregate Industry Productivity." Econometrica 71 (2003): 1695-1725.

Peña, Felix. "Integración regional e inserción internacional de América Latina en un mundo de múltiples opciones." In La agenda internacional de América Latina: entre nuevas y viejas alianzas edited by Dörte Wollrad, Günther Mahold, and Manfred Mols, 97-110. Buenos Aires: Nueva Sociedad, Fundación Friedrich Ebert, Stiftung Wissenschaft und Politik, (2011).

Phillips, Nicola. "The Rise and Fall of Open Regionalism? Comparative Reflections on Regional Governance in the Southern Cone of Latin America." Third World Quarterly 24 (2003): 217-234.

Pomfret, Richard. "Is Regionalism an Increasing Feature of the World Economy?." The World Economy 30 (2007): 923-947.

Soete, Sophie, and Jan Van Hove. Dissecting the Trade Effects of Europe's Economic Integration Agreements Paper presented in the fifteenth annual conference of The European Trade Study Group, Birmingham, September 12-14, (2013).

Soloaga, Isidro, and L. Alan Winters. "Regionalism in the Nineties: What Effect on Trade?. North American Journal of Economics and Finance 12 (2001): 1-29.

Viner, Jacob. The Customs Union Issue. New York: Carnegie Endowment for International Peace, (1950). 


\section{Appendices}

Table A. List of destination countries

\begin{tabular}{|c|c|c|c|}
\hline Afghanistan & Dominican Rep. & Latvia & Seychelles \\
\hline Albania & Ecuador & Lebanon & Sierra Leone \\
\hline Algeria & Egypt & Liberia & Singapore \\
\hline Angola & El Salvador & Libya & Slovakia \\
\hline Argentina & Equatorial Guinea & Lithuania & Slovenia \\
\hline Armenia & Estonia & Madagascar & Somalia \\
\hline Australia & Ethiopia & Malawi & South Africa \\
\hline Austria & Fiji & Malaysia & Spain \\
\hline Azerbaijan & Finland & Mali & Sri Lanka \\
\hline Bahamas & France & Malta & St. Kitts and Nevis \\
\hline Bahrain & Gabon & Mauritania & Sudan \\
\hline Bangladesh & Gambia & Mauritius & Suriname \\
\hline Barbados & Georgia & Mexico & Sweden \\
\hline Belarus & Germany & Mongolia & Switzerland \\
\hline Belgium-Luxembourg & Ghana & Morocco & Syria \\
\hline Belize & Greece & Mozambique & Taiwan \\
\hline Benin & Greenland & Myanmar & Tajikistan \\
\hline Bermuda & Guatemala & Nepal & Tanzania \\
\hline Bolivia & Guinea & Netherlands Antilles & Thailand \\
\hline Bosnia Herzegovina & Guinea Bissau & Netherlands & Togo \\
\hline Brazil & Guyana & New Caledonia & Trinidad and Tobago \\
\hline Bulgaria & Haiti & New Zealand & Tunisia \\
\hline Burkina Faso & Honduras & Nicaragua & Turkey \\
\hline Burundi & Hungary & Niger & Turkmenistan \\
\hline Cambodia & Iceland & Nigeria & UK \\
\hline Cameroon & India & Norway & USA \\
\hline Canada & Indonesia & Oman & Uganda \\
\hline Central African Rep. & Iran & Pakistan & Ukraine \\
\hline Chad & Iraq & Panama & Un. Arab Emirates \\
\hline Chile & Ireland & Papua New Guinea & Uruguay \\
\hline China & Israel & Paraguay & Uzbekistan \\
\hline
\end{tabular}


Table A. List of destination countries

(Continued)

\begin{tabular}{|l|l|l|l|}
\hline China HK SAR & Italy & Peru & Venezuela \\
\hline China MC SAR & Jamaica & Philippines & Vietnam \\
\hline Colombia & Japan & Poland & Zambia \\
\hline Costa Rica & Jordan & Portugal & Zimbabwe \\
\hline Croatia & Kazakhstan & Qatar & \\
\hline Cuba & Kenya & Romania & \\
\hline Cyprus & Kiribati & Russian Fed. & \\
\hline Czech Rep. & Korea Rep. & Rwanda & \\
\hline Czechoslovakia & Kuwait & Samoa & \\
\hline Denmark & Kyrgyzstan & Saudi Arabia & \\
\hline Djibouti & Lao People's Dem. Rep. & Senegal & \\
\hline
\end{tabular}

Table B. Selected sectors

(1962 2009)

\begin{tabular}{|c|l|c|c|c|}
\hline SITC2 & \multicolumn{1}{|c|}{ Description } & $\begin{array}{c}\text { Number of } \\
\text { observations }\end{array}$ & $\begin{array}{c}\text { Participation } \\
\text { in the number of } \\
\text { observations (\%) }\end{array}$ & $\begin{array}{c}\text { Participation } \\
\text { in the value of } \\
\text { exports (\%) }\end{array}$ \\
\hline 78 & $\begin{array}{l}\text { Road vehicles } \\
\text { (incl. air cushion vehicles) }\end{array}$ & 37,172 & 1.85 & 8.47 \\
\hline 77 & $\begin{array}{l}\text { Electrical machinery, apparatus } \\
\text { and appliances n.e.s. }\end{array}$ & 81,889 & 4.07 & 5.33 \\
\hline 68 & Non-ferrous metals & 31,133 & 1.55 & 4.76 \\
\hline 05 & Vegetables and fruit & 79,162 & 3.94 & 3.80 \\
\hline 67 & Iron and steel & 58,628 & 2.92 & 3.17 \\
\hline 74 & $\begin{array}{l}\text { General industrial machinery } \\
\text { and equipment and parts n.e.s. }\end{array}$ & 92,717 & 4.61 & 2.01 \\
\hline 04 & Cereals and cereal preparations & 30,902 & 1.54 & 1.65 \\
\hline 65 & $\begin{array}{l}\text { Textile yarn, fabrics, made-up } \\
\text { articles and related products n.e.s. }\end{array}$ & 102,170 & 5.08 & 1.21 \\
\hline 61 & $\begin{array}{l}\text { Leather, leather manufactures, } \\
\text { n.e.s. and dressed fur skins }\end{array}$ & 30,278 & 1.51 & 0.81 \\
\hline 85 & Footwear & 8,321 & 0.41 & 0.68 \\
\hline & Total & $\mathbf{5 6 9 , 1 6 2}$ & $\mathbf{2 8 . 3}$ & $\mathbf{3 3 . 0 7}$ \\
\hline
\end{tabular}


Figure A. Evolution of the average extensive margins by country

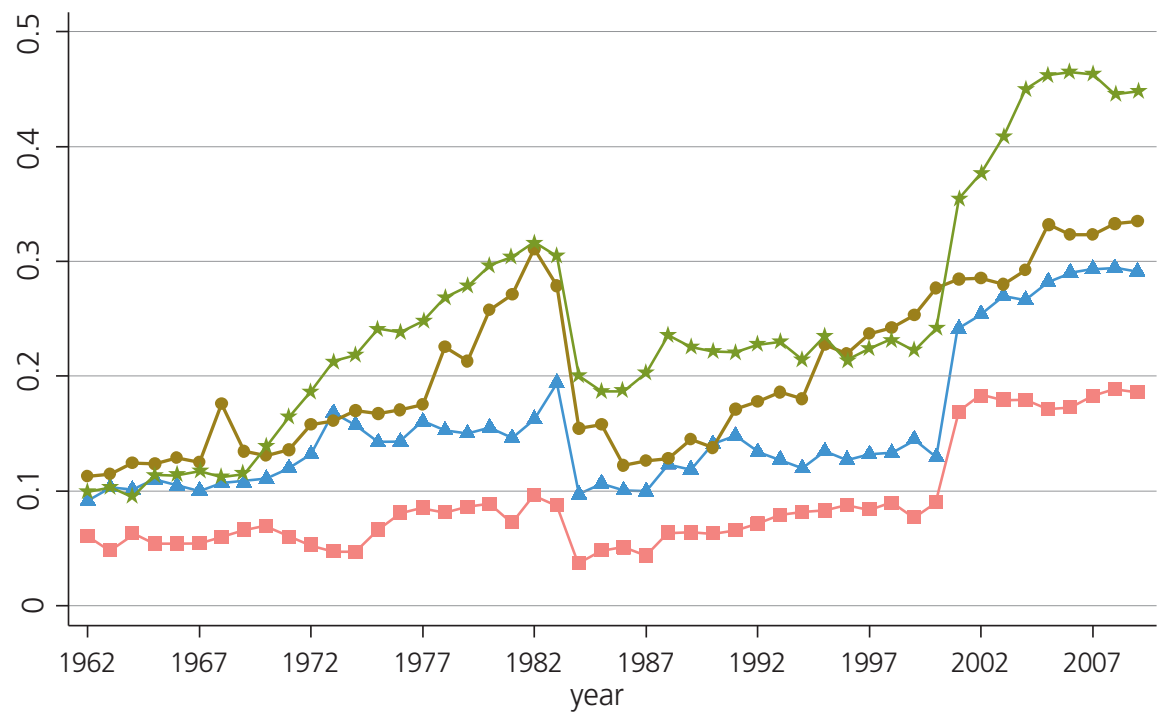

$$
\begin{aligned}
& \longrightarrow \text { av_EM_Argentina } \quad \longrightarrow \text { av_EM_Brazil } \\
& \longrightarrow \text { av_EM_Chile }
\end{aligned}-\text { av_EM_Mexico }
$$


Figure B. Evolution of the average intensive margins by country

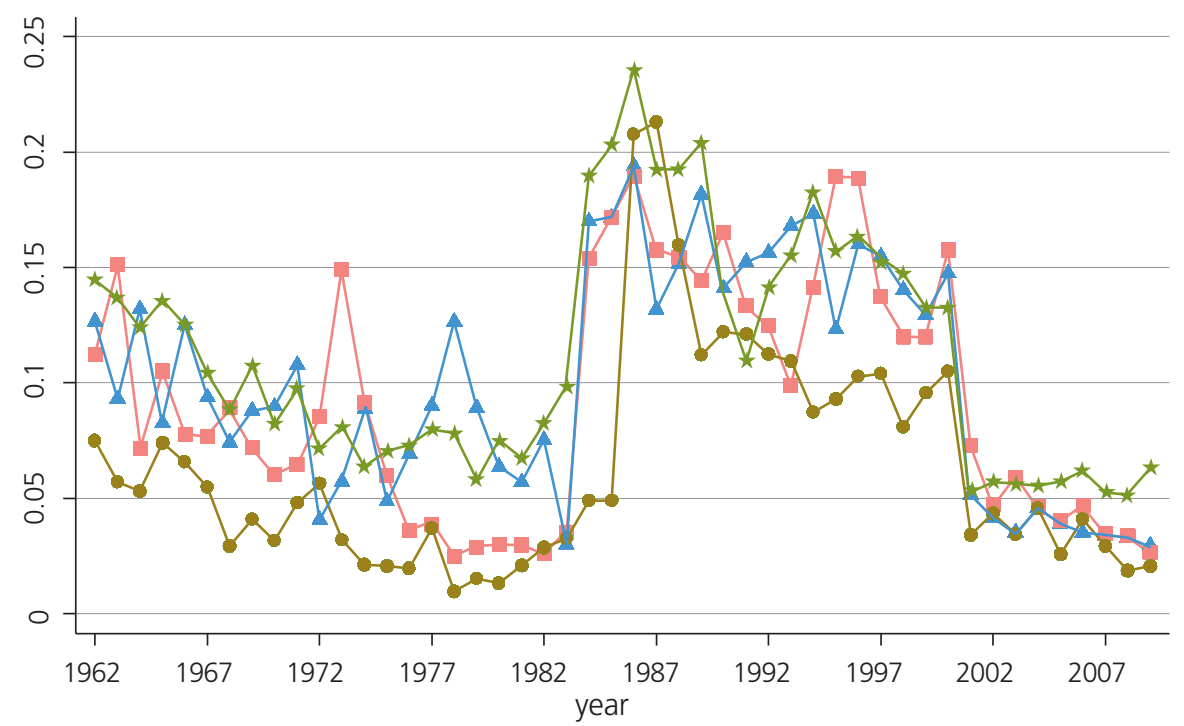

$$
\begin{array}{ll}
\longrightarrow \text { av_IM_Argentina } & \ldots \text { av_IM_Brazil } \\
\longrightarrow \text { av_IM_Chile } & \longrightarrow \text { av_IM_Mexico }
\end{array}
$$

